\title{
Penerapan Teori Tujuan Pemidanaan dalam Perkara Kekerasan terhadap Perempuan: Studi Putusan Hakim
}

\author{
M. Abdul Kholiq dan Ari Wibowo \\ Fakultas Hukum Universitas Islam Indonesia \\ Jl. Tamansiswa No. 158 Yogyakarta \\ kholiq_ibnufattah@yahoo.com; ari_bowo1986@yahoo.com
}

\begin{abstract}
:
This study examines: first, the tendencies in the type and weight of crime in the judge's decision in the criminal case of violence against women. Second, the application of the theory of criminal prosecution. This is a normative-legal research with the legal materials that were analyzed using a descriptivequalitative analysis. From the results of research and discussion conducted, it can be concluded, first: judges always choose to impose the type of imprisonment. The trend for choosing such type was caused by two factors, namely the pattern of criminal threatening in legislation and the nature of crimes of violence against women that substantively is relatively serious. Meanwhile, regarding the weight of sentence imposed, the judge's decisions tend to be various but on average are quite heavy, that is the punishment of 3 (three) to 4 (four) years in jail. Such tendency showed the alignment towards women as the victims of violence crime. The second conclusion showed that the most dominant theories used are the theory of retribution. With the use of this theory it means that judges tend to pay attention to the interests of women as victims.
\end{abstract}

Key words: Crimes of violence against women, the types of crime, criminal weights, the purpose of punishment

\begin{abstract}
Abstrak:
Penelitian ini mengkaji, pertama: kecenderungan jenis dan bobot pidana dalam putusan hakim pada perkara tindak pidana kekerasan terhadap perempuan. Kedua, penerapan teori pemidanaannya. Penelitian ini merupakan penelitian hukum normatif dengan bahan hukum yang dianalisis menggunakan teknik analisis deskriptif-kualitatif. Dari hasil penelitian dan pembahasan yang dilakukan diperoleh kesimpulan: pertama, hakim selalu memilih menjatuhkan jenis pidana penjara. Kecenderungan terhadap pemilihan pidana penjara disebabkan dua faktor, yaitu pola pengancaman pidana dalam perundangundangan dan sifat tindak pidana kekerasan terhadap perempuan yang secara substantif relatif serius. Sementara terkait bobot pidana yang dijatuhkan, putusan hakim cenderung bervariasi dengan rata-rata sudah cukup berat, yaitu pidana penjara antara 3 (tiga) sampai 4 (empat) tahun. Kecenderungan beratnya putusan pidana yang dijatuhkan hakim menunjukkan keberpihakan hakim terhadap perempuan sebagai korban tindak pidana kekerasan. Adapun kesimpulan kedua menunjukkan bahwa teori yang paling dominan digunakan adalah teori retribusi. Dengan penggunaan teori ini berarti hakim cenderung memperhatikan kepentingan perempuan sebagai korban.
\end{abstract}

Kata kunci: Tindak pidana kekerasan terhadap perempuan, jenis pidana, bobot pidana, tujuan pemidanaan 


\section{Pendahuluan}

Norma-norma hukum dalam masyarakat bergantung pada nilai-nilai yang dianut bersama atau penghargaan kolektif (sinngebungen) tentang apa yang baik dan benar sehingga patut diraih. Suatu ketentuan pidana dalam undang-undang merupakan pandangan pembuat undang-undang mengenai nilai-nilai yang hendak dilindungi. ${ }^{1}$ Dengan demikian dapat dikatakan bahwa pembuat undangundang ketika menyatakan kekerasan pada perempuan perlu dikriminalisasi ${ }^{2}$ sebetulnya berkehendak melindungi suatu kepentingan tertentu, yaitu kepentingan asasi perempuan berupa hak untuk mendapatkan perlindungan dan keadilan. Pentingnya perlindungan terhadap perempuan bukan hanya dalam ranah umum namun juga dalam lingkup rumah tangga.

Menguatnya dorongan akan perlunya regulasi yang memberikan perlindungan terhadap perempuan tidak lepas dari fenomena maraknya kekerasan dalam rumah tangga dan umumnya menempatkan perempuan sebagai korbannya. Menurut Committee on the Elimination of Discrimination Against Women (CEDAW), adanya diskriminasi dapat melanggengkan kekerasan terhadap perempuan, misalnya kepercayaan tradisional yang memposisikan perempuan dalam status subordinat atau di bawah pria. ${ }^{3}$

Dalam lingkup rumah tangga, kebebasan para suami dalam melakukan kekerasan terhadap istri seolah-olah dilatarbelakangi oleh doktrin bahwa kaum perempuan yang menikah dianggap telah menjadi hak suami dalam perkawinan. Kepentingan istri ditentukan oleh suami, sehingga ketika suami melakukan kekerasan terhadap istri, maka istri dianggap tidak lagi menjadi persona di bawah hukum. Dalam perkembangannya, kekerasan dalam rumah tangga kemudian diatur secara khusus dalam hukum di Indonesia melalui Undang-Undang No. 23 Tahun 2004 tentang Penghapusan Kekerasan dalam Rumah Tangga (UU PKDRT).

\footnotetext{
${ }^{1}$ Jan Remmelink, Hukum Pidana, Gramedia Pustaka Utama, Jakarta, 2004, hlm. 3.

2 Kriminalisasi merupakan suatu kebijakan dalam menetapkan suatu perbuatan yang semula bukan tindak pidana (tidak dipidana) menjadi suatu tindak pidana (perbuatan yang dapat dipidana). Lihat Barda Nawawi Arief, Kapita Selekta Hukum Pidana, PT. Citra Aditya Bakti, Bandung, 2003, hlm. 240.

${ }^{3}$ Elizabeth M. Misiaveg, "Important Steps and Instructive Models in The Fight to Eliminate Violence Against Women”, Washington and Lee Law Review 1995, hlm. 1118.
} 
Lahirnya UU PKDRT dilatarbelakangi oleh belum cukupnya pengaturan dalam KUHP dalam memberikan perlindungan terhadap perempuan pada lingkup rumah tangga. Sebagai contoh, pengaturan delik perkosaan dalam Pasal 285 KUHP yang dimaknai bahwa korban harus bukan istri sendiri dan harus terjadi dalam bentuk "hubungan seksual" yang dalam keputusan Hooge Raad (Mahkamah Agung Hindia Belanda) 5 Februari 1912 diartikan sebagai "penetrasi penis ke vagina". 4 Pengaturan delik perkosaan tersebut ternyata tidak dirumuskan dari perspektif kepentingan korban (perempuan), misalnya dengan melihat apakah harga diri atau hak asasi perempuan sudah tercabik-cabik? Bagaimana dengan kemungkinan bentuk perkosaan dalam bentuk yang lain?

Selain undang-undang, perlindungan terhadap perempuan bisa dilihat pula dari putusan hakim dalam perkara kekerasan terhadap perempuan. Dalam pertimbangan putusan hakim dapat diketahui kepentingan yang hendak dilindungi. Sebagai contoh, perkara penganiayaan yang dilakukan oleh suami terhadap istri dalam Putusan No. 88/Pid/S/2000/PN Yk. Dalam fakta perkara terungkap bahwa terdakwa dengan inisial SJW pada November 1999 telah melakukan penganiayaan terhadap istrinya yang berinisial HYT. Penganiayaan terjadi karena terdakwa dan korban saling berebutan kunci mobil. Pada saat terjadi perebutan kunci mobil tersebut korban menggigit tangan terdakwa, maka terdakwa langsung memukul korban dengan tangan yang mengenai kepala dan mendengkul mengenai bagian perut korban. Dengan alasan membela diri, terdakwa melakukan penganiayaan hingga mengakibatkan korban menderita dan tidak dapat melakukan aktivitas sehari-hari dengan normal.

Dalam putusannya, hakim menyatakan bahwa terdakwa terbukti melakukan tindak pidana sebagaimana diatur dalam Pasal 351 ayat (1) KUHP dan dijatuhi pidana penjara selama 3 bulan dengan masa percobaan selama 6 bulan. Adapun pertimbangan hakim berkaitan dengan bobot pidana yang dijatuhkan terkait hal-hal yang meringankan: a. Terdakwa memberi keterangan tidak berbelit-belit. b. Mengaku terus terang serta menyesali perbuatannya. c. Terdakwa sebagai pegawai di PT KAI

${ }^{4}$ Harkristuti Harkrisnowo, Hukum Pidana dan Kekerasan terhadap Perempuan, dalam Achie Sudiarti Luhulima (ed.), Pemahaman Bentuk-Bentuk. Tindak Kekerasan terhadap Perempuan dan Alternatif Pemecahannya, Kelompok Kerja Convention Watch dan Pusat Kajian Wanita dan Jender UI, Jakarta, 2000, hlm. 85. 
yang tenaganya sangat dibutuhkan oleh masyarakat. Adapun hal-hal yang memberatkan perbuatan terdakwa dilakukan terhadap istrinya sendiri.

Bandingkan dengan Putusan No. 24/Pid/B/1996/PN Yk tentang perkara pembunuhan yang dilakukan oleh suami terhadap istrinya. Dalam persidangan diperoleh fakta bahwa terdakwa dengan inisial Stn membunuh istrinya sendiri yang berinisial $\mathrm{N}$ secara berencana. Peristiwa ini dilatarbelakangi dendam terdakwa karena dikatakan tidak bertanggung jawab dan tidak waras oleh ibu mertuanya, sehingga terdakwa merasa diancam orang kampung akibat perkataan ibu mertuanya tersebut. Pada suatu hari korban diajak oleh terdakwa ke rumah Ibu Adi di Kuncen untuk memijat, namun setelah terdakwa dan istrinya berada di halaman SD, terdakwa mengatakan kepada istrinya untuk buang air kecil dan istrinya disuruh menunggu. Setelah mengambil linggis, terdakwa menggandeng istrinya untuk diajak pergi ke pojok gedung SD dan korban dipukul dari arah belakang menggunakan linggis secara bertubi-tubi.

Dalam putusannya, hakim menyatakan bahwa terdakwa bersalah melakukan pembunuhan berencana sebagaimana diatur dalam Pasal 340 KUHP. Atas perbuatannya, terdakwa dijatuhi pidana penjara selama 10 tahun dengan mempertimbangkan beberapa hal sebagai berikut. Hal-hal yang meringankan, a. Terdakwa belum pernah dihukum. b. Terdakwa menyesali perbuatannya. Adapun hal-hal yang memberatkan, a. perbuatan terdakwa meresahkan masyarakat. b. Terdakwa seharusnya melindungi istrinya bukan sebaliknya.

Pada perkara yang pertama, hakim hanya menjatuhkan pidana penjara selama 3 bulan dengan masa percobaan selama 6 bulan kepada pelaku kekerasan berupa penganiayaan Pasal 351 ayat (1) KUHP terhadap perempuan. Jika dilihat pidana maksimum Pasal 351 ayat (1) yang berupa pidana penjara 2 tahun 8 bulan, maka putusan tersebut cenderung ringan. Adapun pada perkara kedua, hakim menjatuhkan pidana penjara 10 tahun kepada pelaku kekerasan berupa pembunuhan berencana Pasal 340 KUHP terhadap perempuan. Jika dilihat pidana maksimum Pasal 340 yang berupa pidana mati/ penjara seumur hidup/ penjara 20 tahun, maka putusan tersebut juga cenderung ringan.

Kecenderungan ringannya putusan hakim dalam 2 contoh perkara di atas tentu memiliki alasan-alasan sebagaimana tercermin dalam tujuan pemidanaan 
yang digunakan. Selain itu, putusan pemidanaan yang cenderung ringan terlihat belum menunjukkan keberpihakannya terhadap kepentingan perempuan sebagai pihak yang rentan mengalami kekerasan. Dengan demikian patut dikaji atas dasar teori tujuan pemidanaan apa hakim dalam menjatuhkan putusan pemidanaan dalam perkara-perkara kekerasan terhadap perempuan, juga kepentingan apa yang sebenarnya ingin dilindungi hakim.

Kekerasan yang dimaksud dalam penelitian ini adalah perbuatan yang mengakibatkan terjadinya cidera mental dan/atau fisik. ${ }^{5}$ Dengan demikian, kekerasan tidak hanya berupa kekerasan fisik yang lukanya tampak secara kasat mata, namun juga meliputi kekerasan yang lukanya tidak tampak tetapi dapat dirasakan oleh korban, misalnya trauma, stres, dan lain sebagainya yang dapat mempengaruhi pola kehidupannya.

\section{Rumusan Masalah}

Berdasarkan latar belakang yang telah diuraikan di atas, permasalahan yang diteliti dapat dirumuskan sebagai berikut: pertama, bagaimana kecenderungan jenis dan bobot pidana dalam putusan hakim pada perkara tindak pidana kekerasan terhadap perempuan? Kedua, bagaimana penerapan teori tujuan pemidanaan oleh hakim dalam putusan pemidanaan pada perkara tindak pidana kekerasan terhadap perempuan dan faktor-faktor apa saja yang melatarbelakanginya?

\section{Tujuan Penelitian}

Tujuan penelitian ini adalah: pertama, mengetahui kecenderungan jenis dan bobot pidana dalam putusan hakim pada perkara tindak pidana kekerasan terhadap perempuan. Kedua, mengetahui penerapan teori pemidanaan oleh hakim dalam putusan pemidanaan pada perkara tindak pidana kekerasan terhadap perempuan, serta faktor-faktor apa saja yang melatarbelakanginya.

${ }^{5}$ Soerdjono Soekanto, dalam Aroma Elmina Martha, Perempuan Kekerasan dan Hukum, Dahlan, Yogyakarta, 2003, hlm. 6. 


\section{Metode Penelitian}

Penelitian ini merupakan penelitian hukum normatif ${ }^{6}$ yang mempergunakan dua tahap pengumpulan bahan hukum. Tahap pertama, mempergunakan studi literatur/kepustakaan berupa studi literatur terkait teori-teori pemidanaan. Kemudian pada tahap kedua mempergunakan studi dokumen berupa putusanputusan pengadilan terkait perkara kekerasan terhadap perempuan.

Adapun penentuan lokasi Putusan PN didasarkan pada pertimbangan jumlah perkara kekerasan terhadap perempuan serta kesamaan latar belakang sosial budaya yang mirip. Dari beberapa lokasi yang telah dipertimbangkan diputuskan bahwa putusan yang digunakan meliputi PN Yogyakarta, PN Sleman, PN Klaten dan PN Surakarta. Penelitian ini dibatasi pada putusan yang telah dijatuhkan hakim antara 2003-2006 yang keseluruhan berjumlah 24 putusan. Pembatasan tahun ini didasarkan pada tahun-tahun berkembangnya isu perlunya perlindungan khusus terhadap perempuan di Indonesia. Setelah memperoleh bahan hukum selanjutnya dianalisis menggunakan teknik analisis deskriptif-kualitatif.

\section{Hasil Penelitian dan Pembahasan}

\section{Kecenderungan Putusan Hakim dalam Perkara Tindak Pidana Kekerasan terhadap Perempuan}

\section{Kecenderungan dari Segi Jenis Pidana yang Dijatuhkan}

Dari 24 putusan dapat disimpulkan bahwa hakim masih menjadikan jenis pidana penjara sebagai "sanksi primadona" yang selalu dijatuhkan terhadap pelaku tindak pidana kekerasan terhadap perempuan. Kecenderungan penjatuhan pidana yang seperti ini sebenarnya tidak terlalu mengherankan karena secara umum juga terjadi dalam putusan pemidanaan pada perkara-perkara tindak pidana lain. Hal ini sedikit banyak dipengaruhi oleh faktor pola pengancaman pidana dalam perundang-undangan Indonesia yang memang mengkondisikan

${ }^{6}$ Penelitian hukum normatif adalah penelitian hukum yang mengkaji hukum tertulis dari berbagai aspek antara lain teori dan filosofi. Lihat Abdul Kadir Muhammad, Hukum dan Penelitian Hukum, PT Citra Aditya Bakti, Bandung, 2004, hlm. 101-102. 
aparat penegak hukum (dalam hal ini hakim) untuk selalu menjatuhkan pidana penjara dalam putusannya. Semua perundang-undangan pidana di Indonesia hampir selalu mencantumkan jenis pidana penjara sebagai sanksi hukum terhadap setiap tindak pidana. Pola pengancamannya juga tidak sedikit yang menggunakan pola perumusan tunggal. ${ }^{7}$ Jika tidak berpola perumusan tunggal kebanyakan menggunakan pola perumusan kumulatif ${ }^{8}$ dengan jenis pidana lain seperti denda.

Di samping itu kecenderungan hakim untuk menjatuhkan jenis sanksi pidana penjara juga terkait dengan faktor sifat tindak pidana yang dilakukan terdakwa. Sebagai contoh, pada perkara kejahatan yang relatif cukup serius dan mengkoyak nilai-nilai dan martabat kesetaraan sesama manusia, seperti perkosaan yang menimbulkan trauma panjang pada diri korban, pencabulan terhadap anak di bawah umur yang merusak masa depan korban, persetubuhan tidak sah bersifat incest, dan lain sebagainya. Terhadap jenis tindak pidana yang seperti ini dapat dipahami jika hakim cenderung memilih menjatuhkan jenis pidana penjara sepanjang pilihan pemidanaannya tersebut diorientasikan demi memunculkan dan memberi rasa keadilan kepada korban dan masyarakat, serta memberi efek jera atau pencegahan terhadap pelaku (special prevention) dan masyarakat luas (general prevention).

Dalam perkara kekerasan terhadap perempuan sebagaimana terdapat dalam 24 putusan yang diteliti terlihat bahwa kecenderungan pidana penjara yang dijatuhkan hakim disebabkan perkara yang ditangani merupakan perkara-perkara tindak pidana yang relatif serius, seperti tindak pidana perkosaan (pelanggaran terhadap Pasal 285 KUHP), tindak pidana pencabulan terhadap anak di bawah umur bahkan anak tersebut seharusnya menjadi tanggung jawabnya untuk dilindungi (pelanggaran terhadap Pasal 330 ayat (1) KUHP dan Pasal 294 ayat (1) KUHP), tindak pidana melarikan gadis/ wanita belum dewasa tanpa ijin orang tuanya (pelanggaran terhadap Pasal 332 ayat (1) KUHP), tindak pidana penganiyaan (pelanggaran terhadap Pasal 351 KUHP), dan tindak pidana

${ }^{7}$ Pola perumusan tunggal atau impresif adalah sistem perumusan sanksi pidana sebagai satu-satunya yang diancamkan pada suatu tindak pidana. Lihat Lilik Mulyadi, Kapita Selekta Hukum Pidana, Kriminologi, dan Viktimologi, Penerbit Djambatan, Jakarta, 2007, hlm. 16.

${ }^{8}$ Pola perumusan kumulatif merupakan sistem perumusan sanksi pidana dengan lebih dari dua jenis sanksi pidana untuk suatu tindak pidana. Lihat Ibid., hlm. 17. 
melakukan persetubuhan dengan anak dengan menggunakan kekerasan atau ancaman kekerasan atau dengan menggunakan serangkaian tipu muslihat (pelanggaran terhadap Pasal 81 ayat (1) dan atau Pasal 82 UU No. 23 Tahun 2002 tentang Perlindungan Anak), dan lain-lain. Bahkan dalam beberapa putusan tersebut terlihat juga ada praktik penjatuhan pidana yang mengkumulasikan antara pidana penjara dengan pidana denda sebagai pemberatan pidana karena tindak pidananya dinilai sangat serius. Hal ini terlihat pada 3 putusan di PN Surakarta.

Bertolak dari penjelasan di atas dapat disimpulkan bahwa adanya kecenderungan putusan hakim yang lebih memilih menjatuhkan jenis pidana penjara terhadap para pelaku tindak pidana kekerasan pada perempuan adalah wajar alias dapat dipahami paling tidak disebabkan oleh 2 faktor, yaitu pertama, sebab yang bersumber pada sistem pengancaman pidana dalam perundangundang Indonesia yang memang bersifat mengkondisikan hakim untuk cenderung selalu memilih penjara dalam setiap putusan pemidanaannya. Kedua, sebab yang bersumber pada sifat tindak pidana yang diadili (yakni kekerasan terhadap perempuan) yang secara substantif memang merupakan kejahatan relatif serius.

\section{Kecenderungan dari Segi Bobot Pidana yang Dijatuhkan}

Dari 24 putusan yang diteliti, rata-rata bobot pidana adalah pidana penjara antara 3 sampai 4 tahun. Hanya beberapa putusan saja yang bobotnya berkisar antara 1 sampai 2 tahun penjara. Cukup beratnya bobot pidana yang dijatuhkan hakim dalam perkara ini terlihat pula dari adanya sejumlah putusan yang meskipun sudah menjatuhkan pidana penjara antara 3 sampai 4 tahun atau bahkan ada juga yang antara 5 sampai 7 tahun, tetapi masih juga mengkumulatifkan dengan pidana denda antara Rp. 60.000.000,- sampai Rp. 100.000.000,- Pada putusan hakim PN Surakarta Nomor: 138/Pid.B/2005/PN.Ska, Nomor: 128/Pid.B/2005/PN.Ska, dan Nomor: 142/Pid.B/2005/ PN.Ska, serta Putusan hakim PN Sleman Nomor: 141/PID.B/2006/PN.Slmn, Nomor: 318/Pid.B/2005/PN.Slmn, dan Nomor: 142/Pid.B/2006/PN.Slmn, pemidanaan secara kumulatif dengan menjatuhkan pidana penjara dan denda secara sekaligus dipilih hakim sebagai pemberatan karena perkaranya memang serius, yakni terkait dengan delik persetubuhan 
dengan anak yang menggunakan kekerasan atau ancaman kekerasan atau menggunakan serangkaian tipu muslihat yang akibatnya merusak masa depan anak sebagai korban. Terhadap terdakwa dikenakan Pasal 81 ayat (1) dan/atau Pasal 82 UU No. 23 Tahun 2002 tentang Perlindungan Anak. Penggunaan UU Perlindungan anak dapat dimaknai bahwa hakim sudah memiliki paradigma atau wawasan cukup baik tentang kedudukan anak dan urgensi perlindungan hukumnya demi masa depan anak yang masih panjang.

Untuk perkara pelanggaran terhadap Undang-Undang Perlindungan Anak dimana pelaku melakukan kejahatan menyetubuhi korban dengan menggunakan kekerasan atau ancaman kekerasan, pidana yang dijatuhkan oleh hakim sangat tinggi, yakni 13 tahun penjara dan denda Rp.100.000.000,- Putusan hakim tersebut nyaris mendekati maksimal tuntutan pidana yang diajukan oleh Jaksa Penuntut Umum, yaitu 15 tahun penjara.

Kalaupun ada putusan yang bobotnya relatif ringan, yakni dalam kisaran bulan (kurang dari satu tahun), itu hanya terjadi pada 2 putusan saja, yakni putusan yang dijatuhkan oleh hakim PN Klaten dengan Nomor Putusan: 134/Pid.B/2005/PN.KLT (3 bulan penjara) dan Nomor: 50/Pid.B / 2004/PN. Klt (5 bulan penjara dengan masa percobaan 10 bulan). Ringannya bobot pidana yang dijatuhkan dalam 2 putusan tersebut karena perkara kekerasan terhadap perempuan yang terjadi dan diadili memang dapat dikategorikan sebagai delik yang relatif ringan menurut ketentuan undang-undang hukum pidana yang berlaku, yakni delik penganiayaan ringan sebagaimana diatur dalam Pasal 351 ayat (1) KUHP.

Bertolak dari paparan data dan penjelasan di atas dapat disimpulkan bahwa putusan hakim dalam menjatuhkan pidana kepada para pelaku tindak pidana kekerasan terhadap perempuan relatif berat terutama jika diukur dari bobot pidana dalam tuntutan Jaksa Penuntut Umum. Hal ini dapat dimaknai bahwa di antara aparat penegak hukum (khususnya dalam hal ini Jaksa Penuntut Umum dan Hakim) dalam 24 perkara yang diteliti telah menunjukkan keberpihakan terhadap perempuan sebagai korban tindak pidana kekerasan. 
Teori Tujuan Pemidanaan Paling Dominan yang Diterapkan Hakim dalam Putusan Perkara Tindak Pidana Kekerasan terhadap Perempuan dan Faktor yang Melatar belakanginya

Teori Tujuan Pemidanaan Paling Dominan yang Diterapkan Hakim dalam Putusan Perkara Tindak Pidana Kekerasan terhadap Perempuan

Dari 24 putusan yang diteliti, jika dilihat dari tujuan pemidanaan yang digunakan terdapat 15 putusan yang mencerminkan penggunaan teori retribusi/ pembalasan/absolut ${ }^{9}, 1$ putusan mencerminkan penggunaan teori rehabilitasi ${ }^{10}, 3$ putusan yang mencerminkan penggunaan teori penangkalan/ pencegahan/ tujuan/ relatif ${ }^{11}$, serta 5 putusan yang tidak jelas karena dalam putusannya tidak terdapat pertimbangan yang mencerminkan teori pemidanaan yang digunakan. Dengan demikian, dari 24 putusan yang terkait perkara tindak pidana kekerasan terhadap perempuan, sebagian besar digunakan teori retribusi/ pembalasan/ absolut, yaitu sebesar $62,5 \%$. Secara rinci, tujuan pemidanaan yang digunakan oleh hakim dalam putusan perkara kekerasan terhadap perempuan sebagaimana tersaji dalam Tabel di bawah ini.

Tabel

\begin{tabular}{|c|c|c|c|}
\hline No & No. Putusan & Dasar Pertimbangan Putusan & $\begin{array}{l}\text { Teori Tujuan } \\
\text { Pemidanaan }\end{array}$ \\
\hline 1. & $\begin{array}{l}\text { 72/Pid.B/2006/P } \\
\text { N.YK. }\end{array}$ & Tidak ada & - \\
\hline 2. & $\begin{array}{l}\text { 50/Pid.B/2004/P } \\
\text { N. Klt }\end{array}$ & $\begin{array}{l}\text { Terdakwa harus dijatuhi pidana } \\
\text { yang sesuai dan setimpal dengan } \\
\text { kesalahannya }\end{array}$ & $\begin{array}{l}\text { Teori retribusi/ } \\
\text { pembalasan/ } \\
\text { absolut }\end{array}$ \\
\hline 3. & $\begin{array}{l}\text { 134/Pid.B/2005/P } \\
\text { N.KLT }\end{array}$ & $\begin{array}{l}\text { Terdakwa harus dijatuhi pidana } \\
\text { yang setimpal } \\
\text { perbuatannya }\end{array}$ & $\begin{array}{l}\text { Teori retribusi/ } \\
\text { pembalasan/ } \\
\text { absolut }\end{array}$ \\
\hline 4. & $\begin{array}{l}\text { 100/Pid.B/2004/P } \\
\text { N.SLMN. }\end{array}$ & $\begin{array}{l}\text { Terdakwa harus dijatuhi pidana } \\
\text { sesuai dengan perbuatannya }\end{array}$ & $\begin{array}{l}\text { Teori retribusi/ } \\
\text { pembalasan/ } \\
\text { absolut }\end{array}$ \\
\hline
\end{tabular}

${ }^{9}$ Menurut teori retribusi, tujuan pemidanaan hanyalah untuk pembalasan, tidak ada tujuan-tujuan lain. Lihat Teguh Prasetyo, Kriminalisasi dalam Hukum Pidana, Nusa Media, Bandung, 2010, hlm. 88.

${ }_{10}$ Menurut teori rehabilitasi, tujuan pemidanaan diorientasikan sebagai sebuah langkah penyembuhan bagi pelakunya agar kembali menjadi orang baik. Lihat Sholehudiin, Sistem Sanksi Dalam Hukum Pidana, Cet. Kedua, PT Raja Grafindo Persada, Jakarta, 2003, hlm. 74.

${ }^{11}$ Menurut teori penangkalan, tujuan pemidanaan untuk pencegahan yang ditujukan kepada pelaku agar tidak mengulangi perbuatannya (special prevention) dan ditujukan pula kepada semua orang agar tidak melakukan pelanggaran (general prevention). Lihat Yesmil Anwar dan Adang, Pembaruan Hukum Pidana; Reformasi Pidana, PT Gramedia Widia Sarana Indonesia, Jakarta, 2008, hlm. 135-136. 


\begin{tabular}{|c|c|c|c|}
\hline & $\begin{array}{l}\text { 105/Pid.B/2005/ } \\
\text { PN.Ska }\end{array}$ & $\begin{array}{l}\text { Terdakwa harus dipidana setimpal } \\
\text { dengan perbuatannya }\end{array}$ & $\begin{array}{l}\text { Teori retribusi/ } \\
\text { pembalasan/ } \\
\text { absolut }\end{array}$ \\
\hline 6. & $\begin{array}{l}\text { 43/Pid.B/2005/P } \\
\text { N.Ska }\end{array}$ & $\begin{array}{l}\text { Penjatuhan hukuman kepada } \\
\text { terdakwa bukanlah nestapa atas } \\
\text { perbuatannya, melainkan } \\
\text { dimaksudkan untuk melindungi } \\
\text { terdakwa dan memberikan } \\
\text { kesempatan agar terdakwa dapat } \\
\text { merenung dan tidak mengulangi } \\
\text { lagi perbuatannya }\end{array}$ & $\begin{array}{l}\text { Teori rehabilitasi } \\
\text { dan teori } \\
\text { manfaat } \\
\text { (teleologis) }\end{array}$ \\
\hline 7. & $\begin{array}{l}\text { 138/Pid.B/2005/ } \\
\text { PN.Ska }\end{array}$ & $\begin{array}{l}\text { erdakwa harus dipidana setimpal } \\
\text { engan perbuatannya }\end{array}$ & $\begin{array}{l}\text { Teori retribusi/ } \\
\text { pembalasan/ } \\
\text { absolut }\end{array}$ \\
\hline 8. & $\begin{array}{l}\text { 203/Pid.B/2005/ } \\
\text { PN.Ska. }\end{array}$ & $\begin{array}{l}\text { Terdakwa harus dipidana setimpal } \\
\text { dengan perbuatannya }\end{array}$ & $\begin{array}{l}\text { Teori retribusi/ } \\
\text { pembalasan/ } \\
\text { absolut }\end{array}$ \\
\hline 9. & $\begin{array}{l}\text { 142/Pid.B/2005/ } \\
\text { PN.Ska }\end{array}$ & $\begin{array}{l}\text { 1. Terdakwa harus dipidana setimpal } \\
\text { dengan kesalahannya; dan } \\
\text { 2. Untuk memenuhi rasa keadilan }\end{array}$ & $\begin{array}{l}\text { Teori retribusi/ } \\
\text { pembalasan/ } \\
\text { absolut }\end{array}$ \\
\hline 10. & $\begin{array}{l}\text { 234/Pid.B/2005/ } \\
\text { PN.Ska }\end{array}$ & Tidal & . \\
\hline 11. & $\begin{array}{l}\text { 230/Pid.B/2006/ } \\
\text { PN.Ska }\end{array}$ & $\begin{array}{l}\text { Pidana yang dija } \\
\text { terdakwa telah d } \\
\text { dan adil sesuai de } \\
\text { terdakwa }\end{array}$ & $\begin{array}{l}\text { Teori retribusi/ } \\
\text { pembalasan/ } \\
\text { absolut }\end{array}$ \\
\hline 12. & $\begin{array}{l}\text { 141/PID.B/2006/ } \\
\text { PN.Slmn }\end{array}$ & $\begin{array}{l}\text { Pidana yang dijatuhkan kepada } \\
\text { terdakwa dirasa telah adil sesuai } \\
\text { kesalahan terdakwa }\end{array}$ & $\begin{array}{l}\text { retribusi/ } \\
\text { alasan/ } \\
\text { ut }\end{array}$ \\
\hline 13. & $\begin{array}{l}\text { 364/Pid.B/2006/ } \\
\text { PN.Ska }\end{array}$ & $\begin{array}{l}\text { Pidana yang dijatuhkan terhadap } \\
\text { terdakwa telah dianggap pantas } \\
\text { dan adil sesuai dengan kesalahan } \\
\text { terdakwa }\end{array}$ & $\begin{array}{l}\text { Teori retribusi/ } \\
\text { pembalasan/ } \\
\text { absolut }\end{array}$ \\
\hline 14. & $\begin{array}{l}\text { 128/Pid.B/2005/ } \\
\text { PN.Ska. }\end{array}$ & idak ada & - \\
\hline 15. & $\begin{array}{l}\text { 236/Pid.B/2005/ } \\
\text { PN.Ska }\end{array}$ & $\begin{array}{l}\text { Terdakwa harus dinyatakan } \\
\text { bersalah dan dipidana setimpal } \\
\text { dengan perbuatannya }\end{array}$ & $\begin{array}{l}\text { Teori retribusi/ } \\
\text { pembalasan/ } \\
\text { absolut }\end{array}$ \\
\hline 16. & $\begin{array}{l}\text { 251/Pid.B/2005/ } \\
\text { PN.Slmn. }\end{array}$ & $\begin{array}{l}\text { Majelis Hakim menilai sudah patut } \\
\text { dan setimpal beratnya pidana yang } \\
\text { dijatuhkan }\end{array}$ & $\begin{array}{l}\text { Teori retribusi/ } \\
\text { pembalasan/ } \\
\text { absolut }\end{array}$ \\
\hline
\end{tabular}




\begin{tabular}{|c|c|c|c|}
\hline 17. & $\begin{array}{l}\text { 06/Pid.B/2006/P } \\
\text { N.Slmn. }\end{array}$ & $\begin{array}{l}\text { 1. Terdakwa harus dijatuhi pidana } \\
\text { yang setimpal dengan perbuatannya; } \\
\text { 2. Untuk memenuhi rasa keadilan }\end{array}$ & $\begin{array}{l}\text { Teori } \\
\text { retribusi/ } \\
\text { pembalasan/ } \\
\text { absolut }\end{array}$ \\
\hline 18. & $\begin{array}{l}\text { 11/Pid.B/2006/P } \\
\text { N.Slmn. }\end{array}$ & $\begin{array}{l}\text { Terdakwa harus dijatuhi pidana yang } \\
\text { setimpal dengan perbuatannya }\end{array}$ & $\begin{array}{l}\text { Teori } \\
\text { retribusi/ } \\
\text { pembalasan/ } \\
\text { absolut }\end{array}$ \\
\hline 19. & $\begin{array}{l}\text { 140/PID.B/2005/ } \\
\text { PN.SLM }\end{array}$ & $\begin{array}{l}\text { Terdakwa harus dihukum setimpal } \\
\text { dengan kesalahannya }\end{array}$ & $\begin{array}{l}\text { Teori } \\
\text { retribusi/ } \\
\text { pembalasan/ } \\
\text { absolut }\end{array}$ \\
\hline 20. & $\begin{array}{l}\text { 174/PID.B/2005/ } \\
\text { PN.Slmn }\end{array}$ & Tidak ada & - \\
\hline 21. & $\begin{array}{l}\text { 318/Pid.B/2005/ } \\
\text { PN.Slmn. }\end{array}$ & Tidak ada & - \\
\hline 22. & $\begin{array}{l}\text { 161/Pid.B/2006/ } \\
\text { PN.Slmn }\end{array}$ & $\begin{array}{l}\text { Pemidanaan yang dijatuhkan } \\
\text { terhadap terdakwa bukan merupakan } \\
\text { suatu balas dendam, akan tetapi } \\
\text { merupakan suatu pembinaan supaya } \\
\text { kelak kemudian hari tidak } \\
\text { mengulangi perbuatannya atau dalam } \\
\text { cakupan yang lebih luas supaya tidak } \\
\text { melakukan perbuatan yang } \\
\text { melanggar atau bertentangan dengan } \\
\text { peraturan perundang-undangan }\end{array}$ & $\begin{array}{l}\text { Teori } \\
\text { penangkalan } \\
\text { / } \\
\text { pencegahan/ } \\
\text { tujuan/relatif }\end{array}$ \\
\hline 23. & $\begin{array}{l}\text { 142/Pid.B/2006/ } \\
\text { PN.Slmn }\end{array}$ & $\begin{array}{l}\text { Tujuan pembinaan terhadap diri } \\
\text { terdakwa bukan sebagai unsur balas } \\
\text { dendam akan tetapi bertujuan sebagai } \\
\text { sarana pembinaan bagi terdakwa agar } \\
\text { dapat memperbaiki sikap tingkah } \\
\text { laku dan perbuatannya di kemudian } \\
\text { hari sehingga majelis hakim akan } \\
\text { menjatuhkan putusan yang dirasa } \\
\text { cukup adil bagi hukum }\end{array}$ & $\begin{array}{l}\text { Teori } \\
\text { penangkalan } \\
\text { / } \\
\text { pencegahan/ } \\
\text { tujuan/ relatif }\end{array}$ \\
\hline 24. & $\begin{array}{l}\text { 28/Pid.B/2006/P } \\
\text { N.SLMN }\end{array}$ & $\begin{array}{l}\text { Pemidanaan yang dijatuhkan } \\
\text { terhadap terdakwa bukan suatu balas } \\
\text { dendam akan tetapi merupakan suatu } \\
\text { pembinaan supaya kelak di kemudian } \\
\text { hari tidak mengulangi perbuatannya } \\
\text { atau dalam cakupan yang lebih luas } \\
\text { supaya tidak mengulangi perbuatan } \\
\text { yang melanggar atau bertentangan } \\
\text { dengan peraturan perundang- } \\
\text { undangan. }\end{array}$ & $\begin{array}{l}\text { Teori } \\
\text { penangkalan } \\
\text { / } \\
\text { pencegahan/ } \\
\text { tujuan/ relatif }\end{array}$ \\
\hline
\end{tabular}


Penggunaan teori retribusi/ pembalasan/ absolut terdapat pada 2 putusan PN Klaten, 6 putusan PN Sleman, 7 putusan PN Surakarta, diindikasikan dari pertimbangan putusannya yang menggunakan kalimat sebagai berikut: 1) Terdakwa harus dijatuhi pidana yang sesuai dan setimpal dengan kesalahannya. 2) Terdakwa harus dijatuhi pidana yang setimpal dengan perbuatannya. 3) Terdakwa harus dijatuhi pidana sesuai dengan perbuatannya. 4) Terdakwa harus dipidana setimpal dengan perbuatannya. 5) Terdakwa harus dipidana setimpal dengan kesalahannya dan untuk memenuhi rasa keadilan. 6) Pidana yang dijatuhkan kepada terdakwa telah dianggap pantas dan adil sesuai dengan kesalahan terdakwa. 7) Pidana yang dijatuhkan kepada terdakwa dirasa telah adil sesuai kesalahan terdakwa. 8) Pidana yang dijatuhkan terhadap terdakwa telah dianggap pantas dan adil sesuai dengan kesalahan terdakwa. 9) Terdakwa harus dinyatakan bersalah dan dipidana setimpal dengan perbuatannya. 10) Hakim menilai sudah patut dan setimpal beratnya pidana yang dijatuhkan. 11) Terdakwa harus dihukum setimpal dengan kesalahannya.

Sedangkan teori rehabilitasi dan teori manfaat (teleologis) terdapat pada satu putusan PN Surakarta yang diindikasikan dari pertimbangan putusannya yang menggunakan kalimat: "Penjatuhan hukuman kepada terdakwa bukanlah nestapa atas perbuatannya, melainkan dimaksudkan untuk melindungi terdakwa dan memberikan kesempatan agar terdakwa dapat merenung dan tidak mengulangi lagi perbuatannya." Sementara teori penangkalan/ pencegahan/ tujuan/relatif terdapat pada tiga putusan PN Sleman diindikasikan dari pertimbangan putusannya yang menggunakan kalimat sebagai berikut: 1) Pemidanaan yang dijatuhkan terhadap terdakwa bukan merupakan suatu balas dendam, akan tetapi merupakan suatu pembinaan supaya kelak kemudian hari tidak mengulangi perbuatannya atau dalam cakupan yang lebih luas supaya tidak melakukan perbuatan yang melanggar atau bertentangan dengan peraturan perundang-undangan. 2) Tujuan pembinaan terhadap diri terdakwa bukan sebagai unsur balas dendam akan tetapi bertujuan sebagai sarana pembinaan bagi terdakwa agar dapat memperbaiki sikap tingkah laku dan perbuatannya di kemudian hari sehingga hakim akan menjatuhkan putusan yang dirasa cukup adil bagi hukum. 
Dari hasil penelitian di atas, teori retribusi/pembalasan/absolut merupakan teori yang paling dominan digunakan dalam putusan pengadilan dalam perkara kekerasan terhadap perempuan. Dengan penggunaan teori tersebut, berarti hakim memperhatikan kepentingan korban (offender protection oriented) karena dalam teori retribusi/pembalasan/absolut pemidanaan diharapkan dapat memuaskan perasaan balas dendam si korban, baik dirinya, temannya maupun keluarganya. ${ }^{2}$ Perasaan balas dendam tersebut tidak dapat dihindari dan perlu untuk dihilangkan agar tidak terjadi dendam kesumat yang dapat mengganggu kehidupan harmonis di dalam masyarakat.

Dengan pembalasan terhadap pelaku tindak pidana, maka korban akan terbebaskan dari perasaan balas dendam. Sebagaimana yang dikatakan oleh van Bemmelen bahwa tipe retributif ini tetap penting untuk hukum pidana dewasa ini karena pemenuhan keinginan akan pembalasan (tegemoetkoming aan de vergeldingsbehoeffte) merupakan hal yang sangat penting dalam penerapan hukum pidana agar tidak terjadi "main hakim sendiri". ${ }^{13}$ Jika pelaku tidak mendapatkan balasan berupa pemidanaan, maka potensial akan terjadi main hakim sendiri karena dorongan dari korban, teman atau keluarga korban untuk melakukan pembalasan sendiri kepada pelaku atas kerugian yang ia alami.

Selain memperhatikan kepentingan korban, hakim menggunakan teori retribusi/pembalasan/absolut agar pemidanaan dapat memberikan peringatan kepada pelaku kejahatan dan anggota masyarakat yang lain bahwa setiap ancaman yang merugikan orang lain atau memperoleh keuntungan dari orang lain secara tidak wajar akan menerima pembalasannya. Karena pemidanaan sebagai pembalasan terhadap pelaku atas perbuatannya, maka pemidanaannya harus menunjukkan kesebandingan antara derajat keseriusan perbuatan (the gravity of the offence) dengan pidana yang dijatuhkan. ${ }^{14}$ Implikasinya bahwa pemidanaan yang dijatuhkan kepada pelaku tetap harus memperhatikan derajat keseriusan dari perbuatan yang dilakukan oleh pelaku, sehingga bobot pidananya tidak boleh

\footnotetext{
${ }^{12}$ Romli Atmasasmita, Kapita Selekta Hukum Pidana dan Kriminologi, Mandar Maju, Bandung, 1995, hlm. 83.

${ }^{13}$ Muladi dan Barda Nawawi Arief, Teori-teori dan Kebijakan Pidana, Alumni, Bandung, 1992, hlm. 15.

${ }^{14}$ Ibid., hlm. 84.
} 
melebihi kesalahan pelaku sekalipun tujuannya untuk prevensi umum (general prevention).

Jika dilihat dari bobot pidananya, teori retribusi/pembalasan/absolut digunakan dalam putusan pengadilan yang bobot pidananya di atas 2 (dua) tahun penjara, kecuali dalam putusan No. 50/Pid.B/2004/PN. Klt (pidana penjara 5 bulan dengan percobaan 10 bulan). Sedangkan teori penangkalan / pencegahan /tujuan/relatif cenderung digunakan dalam putusan pengadilan yang bobot pidananya tidak sampai 2 tahun penjara, yaitu putusan No. 161/Pid.B/2006/PN.Slmn (penjara 1 tahun 6 bulan) dan putusan No. 28/Pid.B/2006/PN.SLMN (pidana penjara selama 7 bulan). Hal ini dikecualikan terhadap putusan No. 142/Pid.B/2006/PN.Slmn yang menjatuhkan pidana penjara 3 tahun dan denda Rp. 60.000.000,- subsidair kurungan 1 bulan kepada pelaku. Sementara teori rehabilitasi dan teori manfaat (teleologis) hanya digunakan dalam satu putusan pengadilan dengan pidana penjara 4 tahun.

\section{Faktor-Faktor yang Melatarbelakangi Dominasi Penggunaan Teori Tujuan Pemidanaan}

Hasil penelitian dan analisis sebelumnya menunjukkan bahwa teori retribusi / pembalasan/ absolut paling dominan digunakan oleh hakim dalam perkara tindak pidana kekerasan terhadap perempuan. Teori tersebut cenderung digunakan dalam memutus terdakwa dengan bobot pidana yang relatif berat, yaitu pidana penjara di atas 2 tahun. Keadaan yang memberatkan pemidanaan bagi pelaku menjadi pertimbangan hakim terhadap penggunaan teori tujuan pemidanaan ini. Dari 15 putusan yang menggunakan teori retribusi/ pembalasan/absolut, terdapat beberapa kondisi yang memberatkan terdakwa hingga dijatuhi pidana di atas 2 tahun, yaitu:

“1) Perbuatan terdakwa dilakukan kepada mantan istrinya dan perbuatannya telah menimbulkan rasa sakit dan luka-luka pada diri korban. 2) Perbuatan cabul dilakukan pada anak kandungnya sendiri yang seharusnya terdakwalah yang harus melindungi dari perbuatan-perbuatan yang tidak baik terhadap anaknya. 3) Perbuatan terdakwa telah merusak masa depan korban. 4) Perbuatan terdakwa meresahkan masyarakat, merusak masa depan korban, dan dilakukan secara bersama-sama. 5) Perbuatan terdakwa mengakibatkan trauma pada korban yang umurnya masih anak-anak. 6) Perbuatan terdakwa sangat merusak masa depan korban. 7) Perbuatan terdakwa merusak masa 
depan korban, sudah melakukan kurang lebih 10 kali perbuatan pencabulan, bahkan alat kelamin terdakwa sudah pernah dimasukkan ke dalam lubang kemaluan korban. 8) Perbuatan terdakwa merugikan orang lain terutama korban. 9) Perbuatan terdakwa merusak masa depan korban, dan berdasarkan penelitian BAPAS bahwa korban mengalami keterbelakangan mental. 10) Perbuatan terdakwa merusak masa depan korban. 11) Terdakwa merugikan orang lain khususnya dalam hal perkembangan jiwa korban dan perbuatan terdakwa meresahkan masyarakat. 12) Perbuatan terdakwa merusak masa depan korban dan perbuatannya tidak senonoh sebagai orang tua atau wali yang seharusnya memberi perlindungan, bimbingan, pendidikan terhadap saksi korban selaku anak tirinya akan tetapi terdakwa justru mencabulinya. 13) Perbuatan terdakwa meresahkan masyarakat, mencemarkan nama baik keluarga dan menyebabkan trauma terhadap korban. 14) Perbuatan terdakwa dapat meresahkan masyarakat dan perbuatan terdakwa membuat trauma bagi korban.

Keadaan-keadaan yang memberatkan di atas menjadi pertimbangan hakim untuk menilai bahwa perbuatan terdakwa dinilai serius, sehingga hakim menggunakan teori retribusi/pembalasan/absolut dalam pemidanaan. Pemidanaan sendiri ditentukan sesuai dengan derajat keseriusan dari perbuatan yang dilakukan oleh terdakwa. Berdasarkan keadaan-keadaan yang memberatkan dalam putusan pengadilan, diperoleh beberapa faktor yang melatarbelakangi penilaian hakim terhadap keseriusan perbuatan yang dilakukan oleh terdakwa sehingga menggunakan teori retribusi/pembalasan/absolut dalam pemidanaannya. Faktor-foktor tersebut terkait dengan beberapa aspek, yaitu kondisi korban langsung (direct victim), masyarakat (indirect victim), hubungan pelaku dengan korban langsung, pengulangan perbuatan, serta teknis dalam melakukan perbuatan.

Aspek yang terkait dengan kondisi korban langsung dapat berupa fisik maupun non-fisik. Kondisi fisik korban yang menjadi alasan pemberatan, yaitu karena perbuatan terdakwa menimbulkan rasa sakit dan luka-luka pada diri korban sebagaimana yang dipertimbangkan dalam 1 putusan pengadilan. Sementara terkait kondisi non-fisik korban meliputi: Pertama, merusak masa depan korban sebagaimana dipertimbangkan dalam 7 putusan pengadilan. Kedua, mengakibatkan trauma pada korban sebagaimana dipertimbangkan dalam 3 putusan pengadilan. Ketiga, merugikan orang lain khususnya dalam hal 
perkembangan jiwa korban sebagaimana dipertimbangkan dalam satu putusan pengadilan. Dalam 1 (satu) putusan pengadilan ada kondisi korban yang bukan merupakan akibat dari perbuatan pidana yang dilakukan terdakwa, namun juga dijadikan sebagai alasan pemberat, yaitu mengalami keterbelakangan mental.

Selain terhadap korban langsung, alasan pemberat pemidanaan juga dikaitkan dengan masyarakat sebagai korban tidak langsung dari perbuatan yang dilakukan oleh terdakwa. Sebanyak 4 putusan pengadilan yang mempertimbangkan bahwa perbuatan terdakwa meresahkan masyarakat sehingga layak menjadi alasan pemberatan pemidanaan terhadap terdakwa. Terdapat 1 putusan pengadilan yang mempertimbangkan bahwa perbuatan terdakwa yang mencemarkan nama baik keluarga terdakwa juga layak menjadi alasan pemberatan pemidanaan terhadap terdakwa.

Aspek hubungan pelaku dengan korban langsung yang menjadi alasan pemberatan pidana adalah: Pertama, korban adalah mantan istri pelaku sebagaimana. Kedua, korban adalah anak kandung dari pelaku. Ketiga, korban adalah anak tiri dari pelaku. Dalam pertimbangannya, hakim menjelaskan bahwa sebagai orang tua atau wali yang seharusnya memberi perlindungan, bimbingan, pendidikan terhadap anaknya akan tetapi terdakwa justru mencabulinya.

Aspek pengulangan perbuatan sebagaimana yang dipertimbangkan dalam 1 putusan pengadilan, yaitu karena terdakwa telah melakukan kurang lebih 10 kali perbuatan pencabulan. Sementara terkait aspek teknis perbuatan yang menjadi alasan pemberatan pemidanaan, yaitu berupa perbuatan pelaku yang pernah memasukkan kelaminnya ke dalam lubang kemaluan korban. Perbuatan semacam ini oleh hakim dijadikan sebagai alasan memberatkan pemidanaan karena bentuk pelecehan seksualnya dianggap berat.

Secara fisik, perempuan lebih lemah dari laki-laki, sehingga rentan menjadi korban kekerasan. Selain perempuan, kelompok yang rentan terhadap kekerasan adalah anak. Secara fisik anak lebih lemah dari orang dewasa, demikian juga secara psikis yang belum mampu dengan sempurna membedakan yang baik dan buruk, sehingga anak perlu mendapatkan perlindungan secara khusus. Perlindungan tersebut diwujudkan melalui UU No. 23 Tahun 2002 tentang Perlindungan Anak. Penjelasan Umum UU tersebut menegaskan bahwa pertanggungjawaban orang 
tua, keluarga, masyarakat, pemerintah dan negara terhadap anak merupakan rangkaian kegiatan yang dilaksanakan secara terus-menerus demi terlindunginya hak-hak anak. Rangkaian kegiatan tersebut harus berkelanjutan dan terarah guna menjamin pertumbuhan dan perkembangan anak, baik fisik, mental, spiritual maupun sosial. Tujuan kegiatan ini untuk kehidupan terbaik bagi anak sebagai penerus bangsa.

Dari Penjelasan Umum UU Perlindungan Anak di atas, maka beberapa putusan pengadilan yang menggunakan teori retribusi/ pembalasan/ absolut dalam menentukan pemidanaan sudah tepat. Hakim yang mempertimbangkan kondisi anak yang menjadi korban tindak pidana kekerasan sebagai alasan pemberatan pidana sudah sesuai dengan semangat perlindungan terhadap anak. Dari 14 putusan yang menggunakan teori retribusi/ pembalasan/ absolut, sebanyak 7 putusan pengadilan yang mempertimbangkan bahwa terdakwa yang melakukan perbuatan merusak masa depan korban pantas untuk dijatuhi pidana setimpal.

Dengan melihat pada tujuan pemidanaan yang digunakan serta faktorfaktor yang melatarbelakanginya, dapat disimpulkan bahwa dalam beberapa putusan pengadilan terkait perkara tindak pidana kekerasan terhadap perempuan banyak digunakan teori retribusi/pembalasan/absolut, meskipun dalam beberapa perkara juga digunakan teori penangkalan/pencegahan/tujuan/relatif. Dalam perkara-perkara kekerasan terhadap perempuan yang diteliti, ada pemilahan dalam penggunaan teori tujuan pemidanaan, yaitu terhadap tindak pidana yang relatif berat, maka diutamakan pemidanaan yang mengandung unsur pembalasan, sedangkan dalam tindak pidana yang relatif ringan, maka tujuan pidana dapat lebih ditekankan kepada pribadi pelaku untuk di-resosialisasi. ${ }^{15}$

\section{Penutup}

Berdasarkan pembahasan pada bab sebelumnya, maka dapat diperoleh kesimpulan sebagai berikut: Pertama, dalam perkara kekerasan terhadap

15 Pemilahan yang demikian secara teoritis dapat dibenarkan. Lihat Widodo, Sistem Pemidanaan dalam Cyber Crime, Laksbang Mediatama, Yogyakarta, 2009, hlm. 60. 
perempuan, hakim selalu memilih menjatuhkan jenis pidana penjara kepada terdakwa dan beberapa di antaranya mengkumulasikannya dengan pidana denda. Kecenderungan putusan yang demikian ini disebabkan dua faktor, yaitu pola pengancaman pidana dalam perundang-undangan dan perkara yang diadili secara substantif memang merupakan kejahatan yang relatif serius. Adapun terkait bobot pidana yang dijatuhkan, dari 24 putusan hakim cenderung bervariasi dengan ratarata sudah cukup berat, yaitu pidana penjara antara 3 hingga 4 tahun.

Kedua, teori yang paling dominan digunakan dalam putusan pengadilan pada perkara tindak pidana kekerasan terhadap perempuan adalah teori retribusi/ pembalasan/ absolut, yakni sebesar 62,5\% (15 putusan). Dengan penggunaan teori retribusi/ pembalasan/ absolut yang terlihat dominan tersebut, berarti hakim sudah memperhatikan kepentingan korban (offender protection oriented). Selain memperhatikan kepentingan korban, tujuan penggunaan teori tersebut agar dapat memberikan peringatan kepada pelaku kejahatan dan anggota masyarakat yang lain bahwa setiap ancaman yang merugikan orang lain atau memperoleh keuntungan dari orang lain secara tidak wajar akan menerima pembalasannya yang setimpal. Hakim yang menggunakan teori retribusi/ pembalasan/ absolut cenderung memutus dengan pidana yang relatif berat dengan mempertimbangkan keadaan-keadaan tertentu, seperti kondisi korban langsung (direct victim), masyarakat (indirect victim), hubungan pelaku dengan korban langsung, pengulangan perbuatan, serta teknis dalam melakukan perbuatan.

\section{Daftar Pustaka}

Anwar, Yesmil dan Adang, Pembaruan Hukum Pidana; Reformasi Pidana, PT Gramedia Widia Sarana Indonesia, Jakarta, 2008.

Atmasasmita, Romli, Kapita Selekta Hukum Pidana dan Kriminologi, Mandar Maju, Bandung, 1995.

Elmina Martha, Aroma, Perempuan Kekerasan dan Hukum, Dahlan, Yogyakarta, 2003.

Kadir Muhammad, Abdul, Hukum dan Penelitian Hukum, PT Citra Aditya Bakti, Bandung, 2004.

M. Misiaveg, Elizabeth, "Important Steps and Instructive Models in The Fight to Eliminate Violence Against Women", Washington and Lee Law Review. 1995. 
Muladi dan Barda Nawawi Arief, Teori-teori dan Kebijakan Pidana, Alumni, Bandung, 1992.

Mulyadi, Lilik, Kapita Selekta Hukum Pidana, Kriminologi, dan Viktimologi, Penerbit Djambatan, Jakarta, 2007.

Nawawi Arief, Barda, Kapita Selekta Hukum Pidana, PT. Citra Aditya Bakti, Bandung, 2003.

Remmelink, Jan, Hukum Pidana, Gramedia Pustaka Utama, Jakarta, 2004.

Sudiarti Luhulima, Achie (ed.), Pemahaman Bentuk-Bentuk Tindak Kekerasan terhadap Perempuan dan Alternatif Pemecahannya, Kelompok Kerja Convention Watch dan Pusat Kajian Wanita dan Jender UI, Jakarta, 2000.

Sholehudiin, Sistem Sanksi dalam Hukum Pidana, Cet. Kedua, PT Raja Grafindo Persada, Jakarta, 2003.

Widodo, Sistem Pemidanaan dalam Cyber Crime, Laksbang Mediatama, Yogyakarta, 2009. 